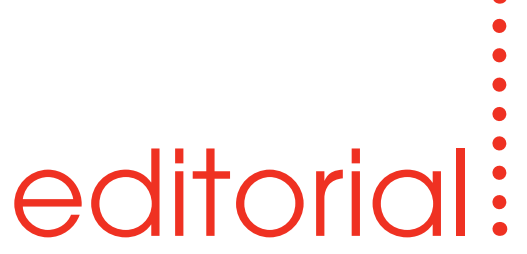

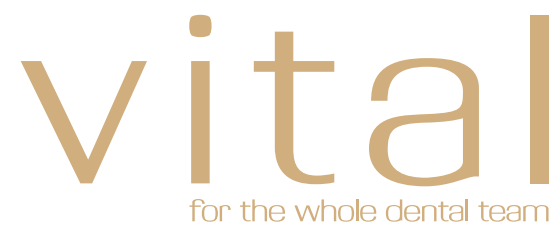

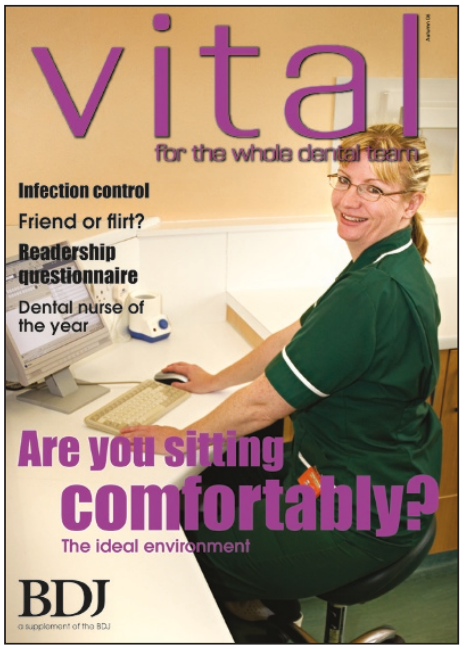

Cover feature photography by: Filskifoto Filip Gierlinski

Mobile: 07859078945

Email: filski77@hotmail.com

The dental nurse shown is seated on a Bambach Saddle Seat. For more information on Bambach products see www.bambach. co.uk or telephone 0800581108

Editor-in-Chief: Stephen Hancocks OBE Editor: Kate Maynard

Art Editor: Melissa Cassem

Production Editor: Esther McKeown

Staff writers: Rowena Milan, Arveen Bajaj

Publishing Manager: Kim Black-Totham Advertising Sales Director: Joe Aspis Senior Advertising Executive: Alison Tant Advertising enquiries: +44 (0)20 78434729 Production Controller: Ian Pope

Vital Editorial Board: Julia Brewin, Michelle Brindley, Larry Browne, Claire Crocker, Ruth Glover, Gordon Watkins, Margaret Wilson

British Dental Journal

The Macmillan Building

4-6 Crinan Street

London N19XW

Tel: + $44(0) 2078433678$

Fax: + $44(0) 2078434725$

(c) British Dental Journal 2006. All rights reserved. No part of this publication may be reproduced, stored in a retrieval system or transmitted in any form or by any means, electronic, mechanical, photocopying, recording or otherwise, without the prior permission of the British Dental Journal.

The opinions expressed in this publication are those of the authors and not necessarily those of the British Dental Association or the editor. Appearance of an advertisement does not indicate BDA approval of the product or service.

\section{Comfort control}

The holiday season is over, and with any luck you're feeling refreshed and full of energy to get stuck back into work. On the other hand, you might go home at the end of each day feeling drained, achy and craving comfort foods. If so, perhaps your team need to reassess the design of your work environment. Tim Hutchful provides some useful tips for ergonomicallyfriendly surgeries on page 39 .

If mounting a saddle seat just isn't enough to dispel your dread at the thought of the long winter ahead, turn to page 15 for the opportunity to win a trip to a little oasis in the English countryside. My colleague and I gave it a test-run earlier this year, just to make sure it was good enough for Vital readers.

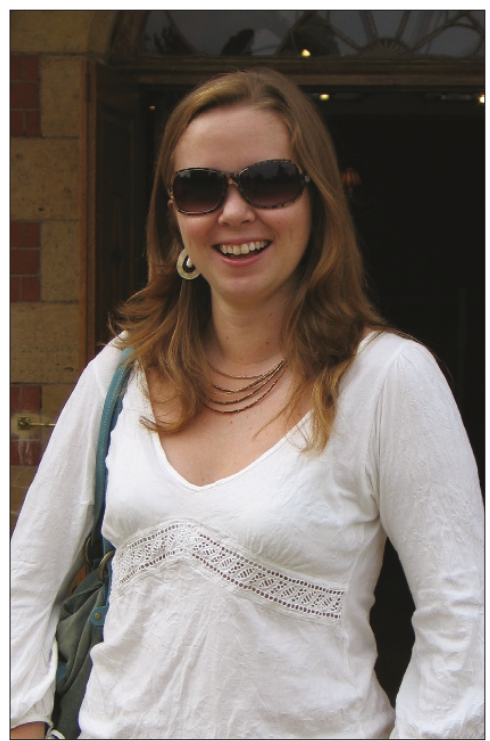

Karen Bell is one dental nurse used to beating off the competition as far as winning prizes are concerned. Find out just how she does it on page 20.

Despite being voted Dental Nurse of the Year 2006, Karen continues to further her skills by signing up for training courses. Along with our usual Spotlight feature, which in this issue is on hygienists, we have also provided a detailed guide to DCP schools and courses across the country (page 30). Be sure to check what your local colleges have on offer as well.

The best place to start fine-tuning your brain cells is, however, right at your fingertips. The Vital Guide Series not only gives you a crash course in infection control on page 23, but also enables you to check how much has sunk in with the ever-popular CPD questions.

So, with the posture of a ballet dancer and thoroughly decontaminated, you'll be fighting fit to have a go at one of the activities on pages 43-45. Our busy lifestyle writers have plenty to recommend.

If you haven't found something to interest you in this issue of Vital (not even reading about flirty working relationships on page 35?), and if you still haven't got round to subscribing, then now is your chance to let us know. To mark our three-year anniversary we have decided to include a questionnaire to collate your views. Be sure to send us a photo if you win the stylish prize.

Look out for the results in a forthcoming issue of Vital. Who knows, it might be your surgery gracing the cover next time ... get scribbling!

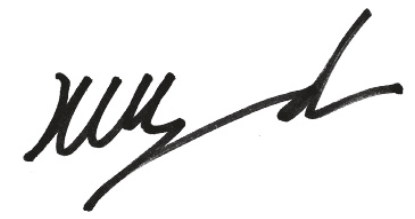

Kate Maynard, Editor

k.maynard@nature.com 